\author{
MARIA SzMIDT, DOMINIKA GRANDA, AdRIAN BRODA, ANNA BRZOZOWSKA \\ Katedra Żywienia Człowieka \\ Wydział Nauk o Żywieniu Człowieka i Konsumpcji \\ Szkoła Główna Gospodarstwa Wiejskiego w Warszawie \\ Nowoursynowska 159C, 02-787 Warszawa \\ E-mail: maria_szmidt@sggw.pl
}

\title{
ROLA WARZYW I OWOCÓW W DIECIE OSÓB STARSZYCH
}

\section{WSTEP}

Wraz $z$ posteppem medycyny średnie trwanie życia człowieka stale się wydłuża (WHo 2015a). Światowa Organizacja Zdrowia (WHO) przewiduje, że do 2050 r. liczba osób w wieku powyżej 60 lat ulegnie podwojeniu, stanowiacc wówczas $22 \%$ całej ludności na świecie (WHO 2015b). Jednocześnie raporty WHO wskazuja na stale wzrastajacą liczbę osób $z$ chorobami przewlekłymi, spośród których wiele pojawia się w wieku starszym i może zwiększać ryzyko niepełnosprawności i utraty niezależności seniora. W zwiazku $z$ tym jednym $z$ głównych wyzwań zdrowia publicznego jest zadbanie o zdrowie osób starszych tak, aby wraz $z$ wydłużeniem życia wzrastał jednocześnie wskaźnik HLY (ang. healthy life years) mówiacy o liczbie lat przeżytych $\mathrm{w}$ zdrowiu. Jednym $\mathrm{z}$ kluczowych elementów dla zachowania zdrowia jest racjonalne $\dot{z} y w i e n i e, w$ tym odpowiednie spożycie warzyw i owoców.

Starzenie się organizmu to złożony i długotrwały proces, który postępuje niezależnie od woli człowieka. Wraz $z$ jego postępem następuje upośledzenie istotnych funkcji fizjologicznych organizmu, m.in. pogorsza się funkcjonowanie układu krażenia, układu immunologicznego i wydolność oddechowa. Zmiany zachodzace w przewodzie pokarmowym (m.in. obniżenie funkcji motorycznej, ograniczenie enzymatycznego trawienia pokarmu oraz wydajności wchłaniania) zmniejszaja zdolność absorpcji odpowiednich ilości składników odżywczych (RÉMOND i współaut. 2015). Ponadto, w wieku starszym dochodzi do zaburzeń odczuwania pragnienia i sy- tości, smaku i zapachu pokarmu, a także ubytków uzębienia i zmniejszenia objętości wydzielanej śliny, co bezpośrednio wpływa na ilość spożywanego pokarmu. Częsta konsekwencja powyższych zmian jest unikanie potraw i produktów, które sprawiaja trudności w spożyciu, co finalnie może prowadzić do niedoborów wielu składników odżywczych i niedożywienia organizmu.

Zmiany zachodzace w organizmie w wieku starszym, zarówno o charakterze fizjologicznym, jak i zwiazane $z$ pojawianiem się chorób powoduja, że $z$ wiekiem następuje m.in. zmniejszenie zapotrzebowania na energie oraz tłuszcz, natomiast wzrasta zapotrzebowanie na pełnowartościowe białko, wapń, witaminę D czy witaminy $z$ grupy $B$ (kwas foliowy, $B_{6}$, $\left.\mathrm{B}_{12}\right)$. Powoduje to, że w żywieniu osób starszych ważna rolę odgrywa gęstość odżywcza pożywienia. Wymaga to odpowiedniego doboru produktów tak, aby przy zmniejszonej wartości energetycznej całej diety, zawartość w niej składników pokarmowych, szczególnie mikroskładników, była na odpowiednim poziomie.

Aktualnie w „Piramidzie Zdrowego Żywienia i Aktywności Fizycznej dla osób w wieku starszym" oraz zwiazanych $z$ nia zaleceniach (JAROsz, 2018) wskazuje się, że podstawa żywienia osób starszych powinny być warzywa i owoce, stanowiąc co najmniej połowę spożywanej żywności. W przypadku, kiedy produkty te nie sa dobrze tolerowane, można spożywać je w formie rozdrobnionej, przetartej lub w postaci soków (do 200-400 $\mathrm{ml} /$ dobę). Na wyższych piętrach piramidy, co oznacza proporcjonalnie mniejszą ilość i częstość spożywania, znajdują się produkty 
zbożowe, mleczne, chude mięsa, ryby, jaja i nasiona roślin straczkowych. Najwyższe piętro piramidy zajmuja dobrej jakości oleje roślinne i orzechy. Ponadto, w piramidzie uwzględniono zalecenia dotyczace ograniczenia spożycia cukru, słodyczy oraz dosalania, wypijania co najmniej 2 litrów płynów dziennie oraz niespożywanie alkoholu. Natomiast podstawę piramidy stanowi codzienna aktywność fizyczna i umysłowa.

\section{ROLA WARZYW I OWOCÓW W DIECIE OSÓB STARSZYCH}

Pomimo tego, że nie można zatrzymać procesu starzenia się, to można wplywać na jego przebieg modyfikując czynniki zewnętrzne, takie jak dieta, poziom aktywności fizycznej czy zaangażowanie społeczne, które $\mathrm{w}$ dużym stopniu determinuja starzenie się wtórne.

Odpowiednia ilość warzyw i owoców w zdrowej diecie, zawierającej mało nasyconych kwasów tłuszczowych, cukrów prostych i soli, zmniejsza ryzyko wielu chorób dietozależnych i ryzyko zgonu. Dlatego od wielu lat zaleca się codzienne spożywanie co najmniej 5 porcji produktów $z$ tej grupy.

Warzywa i owoce odgrywaja istotna role $\mathrm{w}$ dostarczeniu do organizmu wielu składników pokarmowych niezbędnych dla utrzymania prawidłowego zdrowia, takich jak potas, foliany, magnez, cynk, selen, prowitamina A, witamina C. Ze względu na stres oksydacyjny towarzyszacy stanom zapalnym uważanym za jedna $z$ przyczyn starzenia się organizmu (SANTORO i współaut. 2014), warzywa i owoce sa ważne $\mathrm{w}$ diecie, ponieważ dostarczaja antyoksydanty, takie jak karotenoidy, antocyjany, flawonoidy, tokoferole czy witamina C. Jedna porcja warzyw i owoców może zwiększyć o $24 \%$ spożycie witaminy C oraz o $20 \%$ spożycie $\beta$-karotenu z dieta (FULTON i wspołaut. 2017), a zwiększenie spożycia $z \quad 3$ do około 8 porcji na dzień istotnie zwiększa stężenie w osoczu witaminy C, folianów i różnych karotenoidów (DUTHIE i współaut. 2018).

Spożycie warzyw i owoców na zalecanym poziomie dostarcza również odpowiednia ilość błonnika pokarmowego, który między innymi wspomaga perystaltyke i utrzymanie prawidłowej mikrobioty jelit. U osób starszych często występuja problemy z biegunkami lub zaparciami, natomiast spożycie błonnika pokarmowego $z$ warzywami i owocami wydłuża czas pasażu jelitowego, tworząc zwiększoną masę, która pozwala na stopniowe wchłanianie składników odżywczych, jednocześnie zapobiegajac zaparciom (CLIFFORD i współaut. 2010). Wraz $z$ wiekiem dochodzi do dekompozy- cji mikrobioty jelitowej (BIAGI i współaut. 2013), m.in. zmniejszeniu ulega liczba i różnorodność bakterii $z$ rodzaju Bifidobacteria, natomiast wzrasta $\mathrm{z}$ rodzaju Bacteroides (KUMAR i wspołaut. 2016). Błonnik pokarmowy spożywany $z$ warzywami i owocami, pełniąc rolę prebiotyku, wspiera rozwój korzystnych drobnoustrojów, co jest niezwykle ważne dla ogólnego stanu zdrowia, gdyż odpowiada m.in. za funkcjonowanie układu odpornościowego, prawidłowe wchłanianie składników pokarmowych, metabolizm cholesterolu czy syntezę krótkołańcuchowych kwasów tłuszczowych, które wykazuja właściwości przeciwnowotworowe (LATTIMER i HAUB 2010, KUMAR i współaut. 2016). Skład mikrobioty jelitowej u osób starszych istotnie koreluje $\mathrm{z}$ zespołem słabości, stanem odżywienia oraz markerami stanu zapalnego (CLAESSON i współaut. 2012).

W wielu badaniach wykazano korzystny wpływ zwiększonego spożycia warzyw i owoców na obniżenie ryzyka wystapienia chorób układu sercowo-naczyniowego. Na podstawie meta-analizy obejmujacej ponad 330 tys. pacjentów stwierdzono, że osoby $z$ największym spożyciem warzyw i owoców charakteryzowały się o $19 \%$ mniejszym ryzykiem wystapienia nadciśnienia tętniczego, w stosunku do osób $z$ najniższym spożyciem tych produktów (LI i współaut. 2016). Podobną zależność wykazano w przypadku niewydolności serca (RAUTIAINEN i współaut. 2015). Kobiety spożywajace najwięcej warzyw i owoców ogółem $(\geq 6,9$ porcji/dobę) charakteryzowały się o $20 \%$ niższym ryzykiem wystapienia tego schorzenia, $w$ porównaniu do osób $z$ najniższego kwintyla spożycia ( $\leq 2,9$ porcji/dobę). Wykazano również protekcyjny wpływ spożycia warzyw i owoców w odniesieniu do wystapienia choroby niedokrwiennej serca. Osoby, które spożywały powyżej 5 porcji/ dobę charakteryzowały się o $17 \%$ niższym ryzykiem wystapienia tej jednostki chorobowej, w porównaniu do osób spożywających mniej niż 3 porcje warzyw i owoców dziennie (HE i współaut. 2007). Ponadto, spożycie warzyw i owoców na poziomie co najmniej zalecanym związane jest $z$ obniżeniem ryzyka osteoporozy (PARK i współaut. 2011), cukrzycy typu 2 (SCHWINGSHACKL i współaut. 2017), a także przewlekłej obturacyjnej choroby płuc (KAŁUŻa i współaut. 2017)

Wyniki wielkiego europejskiego badania BOFFETTA i współaut. z 2010 r., w którym udział wzięło blisko 480 tys. osób wykazały, że duże spożycie warzyw i owoców ( $\geq 647$ $\mathrm{g} / \mathrm{d})$ obniża ryzyko wystapienia wszystkich rodzajów nowotworów o 11\%. Szczególna 
rolę warzywa i owoce odgrywaja w przypadku prewencji/opóźnienia wystąienia raka jelita grubego. W metaanalizie wykonanej przez KASHINO i współaut. (2015) duże spożycie warzyw, w porównaniu do małego, związane było $z$ obniżeniem ryzyka wystapienia tego nowotworu o 25\%. Spożycie owoców i warzyw przez osoby starsze może chronić przed rozwojem różnych rodzajów nowotworów, zarówno wśród mężczyzn, jak i kobiet (NICKLETT i KADELL 2013).

Wyniki badania PolSenior wskazuja, że występowanie zaburzeń funkcji poznawczych (m.in. percepcja, pamięć, uwaga) wśród Polaków w wieku powyżej 65 lat jest zjawiskiem powszechnym. Łagodne zaburzenia poznawcze wystapiły u 36,3\% badanych, a otępienie u 32,0\% (KLICH-RACZKA i wspó1aut. 2012). W licznych badaniach epidemiologicznych wykazano wpływ czynników żywieniowych na ryzyko wystapienia zaburzeń poznawczych, przy czym szczególna uwage zwrócono na warzywa i owoce. Spożycie warzyw i owoców na poziomie $\geq 400 \mathrm{~g} /$ dobę związane było $z$ istotnie mniejszym (o $47 \%$ ) ryzykiem wystapienia zaburzeń funkcji poznawczych (PASTOR-VALERO i współaut. 2014), a zwiększenie spożycia tych produktów o każde $100 \mathrm{~g} /$ dobę związane było $\mathrm{z}$ $13 \%$ obniżeniem ryzyka wystapienia zaburzeń poznawczych oraz demencji (JIANG i współaut. 2017). Jak wskazują ZIELIŃSKA i współaut. (2017), spożycie tych produktów spożywczych w zalecanych ilościach (5 porcji dziennie) zwiększa potencjał antyoksydacyjny surowicy krwi oraz zmniejsza ryzyko wystąpienia chorób neurodegeneracyjnych wśród osób starszych.

Jednym $z$ wyzwań profilaktyki chorób osób starszych jest zapobieganie i łagodzenie skutków depresji dotykajacej 15-20\% seniorów (PUŻYŃSKI 2009). W związu $z$ tym naukowcy, oprócz innych uwarunkowań np. psychospołecznych czy środowiskowych, takich jak siedzacy tryb życia czy mała/duża liczba godzin snu, poszukują również czynników ryzyka wystąpienia tej jednostki chorobowej w diecie seniorów. Badania wskazują, że większe spożycie warzyw, a także owoców związane jest $z$ obniżeniem ryzyka depresji odpowiednio o $14 \%$ i $11 \%$ w porównaniu do najniższej kategorii spożycia (LIU i współaut. 2016). Ponadto, spożywanie więcej niż 7 porcji warzyw i owoców, w porównaniu do spożycia 0-4 porcji/dobę, może obniżać występowanie niepokoju psychicznego wśród osób starszych o 18\% (NGUYEN i współaut. 2017). Wykazano również, że zwiększone spożycie warzyw i owoców zwiazane jest $z$ wyższym poziomem odczuwania szczęścia, satysfakcji z życia i dobrego samopoczucia (MUJCIC i Oswald 2016).
Wiele danych wskazuje na istotny związek między spożyciem warzyw i owoców a ryzykiem śmiertelności wśród osób starszych (NICKLET i KADELL 2013). W badaniu $z$ udziałem ponad 70 tys. osób wykazano, że w porównaniu do spożywania 5 porcji warzyw i owoców na dobę, mniejsze spożycie tych produktów było zwiąane $z$ krótszym przeżyciem i większą śmiertelnością w grupie (BEllavia i współaut. 2013). Osoby w ogóle nie spożywające warzyw i owoców żyły 3 lata krócej oraz charakteryzowały się o 53\% wyższym ryzykiem zgonu, w stosunku do osób spożywajacych 5 porcji warzyw i owoców dziennie. Natomiast spożywanie powyżej 7 porcji dziennie owoców i warzyw ogółem wiązało się istotnie $z$ obniżeniem o $25 \%$ śmiertelności $z$ powodu nowotworów oraz o $31 \%$ z powodu chorób układu krążenia (OYEBODE i współaut. 2014). W australijskim badaniu kohortowym również wykazano, że spożycie około 7 porcji warzyw i owoców dziennie istotnie zmniejszało ryzyko zgonu o 10\% (NGUYEN i współaut. 2016).

\section{SPOŻYWANIE WARZYW I OWOCÓW PRZEZ OSOBY STARSZE}

Biorac pod uwage istotna rolę warzyw i owoców w żywieniu osób starszych istotne sa działania edukacyjne i motywujace ich do zwiększonego spożywania produktów $Z$ tych grup. Badanie przeprowadzone przez zespół z Katedry Żywienia Człowieka SGGW objęło 91 słuchaczy Uniwersytetów Trzeciego Wieku (UTW) z Milanówka i Grodziska Mazowieckiego. Pytania kwestionariuszowe dotyczyły m.in. częstotliwości spożywania w ciagu ostatnich trzech miesięcy warzyw ogółem i 11 różnych grup warzyw/przetworów warzywnych oraz owoców ogółem i 11 grup owoców/przetworów owocowych. Za każda $z \quad 8$ możliwych odpowiedzi określających częstotliwość spożycia przyznawane były punkty w skali od 1 do 8, rosnaco i odpowiednio dla wskazania: 1 - nigdy, 2 - raz lub rzadziej $\mathrm{w}$ miesiaccu, 3 - od dwóch do trzech razy w miesiącu, 4 - raz, dwa razy $\mathrm{w}$ tygodniu, 5 - trzy/cztery razy w tygodniu, 6 - od pięciu do sześciu razy w tygodniu, 7 - raz na dzień, 8 - dwa do trzech razy na dzień. W przypadku braku odpowiedzi w obrębie podgrupy uznawano, że respondent nie spożywał danych produktów, zaznaczając częstotliwość jako "nigdy” i przyznając jeden punkt. Średnia wieku badanych kobiet $(n=71)$ wyniosła 68 lat, a mężczyzn $(n=19)$ prawie 69 lat. Badane osoby w większości zamieszkiwały obszar miejski (58\%), posiadały wykształcenie wyższe $(44 \%)$ lub średnie $(46 \%)$ oraz deklarowały występowanie chorób (89\%). 
Tabela 1. Częstość spożycia warzyw i owoców w zależności od parametrów/cech związanych ze zdrowiem.

\begin{tabular}{|c|c|c|c|c|c|}
\hline \multirow[b]{2}{*}{ Kategoria } & \multirow[b]{2}{*}{$\begin{array}{l}\text { Liczba osób } \\
\text { w kategorii }\end{array}$} & \multicolumn{2}{|l|}{ Warzywa } & \multicolumn{2}{|l|}{ Owoce } \\
\hline & & $\begin{array}{l}\text { Częstość spoży- } \\
\text { wania (pkt) } \\
x \pm \text { od.st. }\end{array}$ & $\begin{array}{l}\text { Test } t \text {-Studenta } \\
\text { (wartość } p \text { ) }\end{array}$ & $\begin{array}{l}\text { Częstość spożywa- } \\
\text { nia (pkt) } \\
x \pm \text { od.st. }\end{array}$ & $\begin{array}{l}\text { Test } t \text {-Studenta } \\
\text { (wartość } p \text { ) }\end{array}$ \\
\hline Kobiety & 71 & $6,68 \pm 1,18$ & NS & $7,21 \pm 1,03$ & NS \\
\hline Mężczyźni & 19 & $6,42 \pm 1,23$ & & $6,63 \pm 1,13$ & \\
\hline \multicolumn{6}{|c|}{ Proteza zębowa } \\
\hline Nie & 29 & $6,93 \pm 1,14$ & NS & $7,41 \pm 0,89$ & 0,0314 \\
\hline Tak & 61 & $6,48 \pm 1,20$ & & $6,93 \pm 1,14$ & \\
\hline \multicolumn{6}{|c|}{ Problemy z gryzieniem } \\
\hline Nie & 69 & $6,62 \pm 1,21$ & NS & $7,22 \pm 1,08$ & 0,0197 \\
\hline Tak & 21 & $6,62 \pm 1,17$ & & $6,67 \pm 0,99$ & \\
\hline \multicolumn{6}{|c|}{ Problemy z żuciem } \\
\hline Nie & 71 & $6,63 \pm 1,19$ & NS & $7,24 \pm 1,00$ & 0,01362 \\
\hline Tak & 19 & $6,58 \pm 1,12$ & & $6,53 \pm 1,19$ & \\
\hline \multicolumn{6}{|c|}{ Spadek/utrata apetytu } \\
\hline Nie & 80 & $6,71 \pm 1,19$ & 0,0249 & $7,11 \pm 1,07$ & NS \\
\hline Tak & 10 & $5,90 \pm 1,04$ & & $6,90 \pm 1,14$ & \\
\hline
\end{tabular}

NS $-p>0,05$

\section{CZYNNIKI ZWIAZZANE Z CZESTOŚCIA SPOŻYWANIA WARZYW I OWOCÓW PRZEZ OSOBY STARSZE}

Średnie częstości spożywania warzyw ogółem dla kobiet i mężczyzn nie różniły się istotnie (Tabela 1) i wskazywały, że w badanej grupie były osoby, które nie jadały warzyw codziennie. Jedynie 21\% mężczyzn i $30 \%$ kobiet deklarowało, że spożywaja warzywa 2-3 razy w ciagu dnia. Podobnie nie stwierdzono istotnych różnic między kobietami i mężczyznami odnośnie częstości spożywania owoców ogółem (Tabela 1), ale wśród mężczyzn byli tacy, którzy nie jadali owoców codziennie. W badanej grupie nieco więcej osób deklarowało częstsze spożywanie owoców niż warzyw, tj. u 32\% mężczyzn i 51\% kobiet częstość spożywania owoców wynosiła 2-3 razy na dzień. Aż $42 \%$ respondentów jadało warzywa i owoce jedynie raz lub dwa razy $\mathrm{w}$ ciagu dnia. Znajduje to potwierdzenie $\mathrm{w}$ badaniach zagranicznych, w których stwierdzono, że mniej niż połowa osób starszych spożywa 5 porcji warzyw i owoców w ciagu dnia (NICKLETT i KADELL 2013).

Częstość spożywania warzyw ogółem i owoców ogółem nie była zróżnicowana w grupie badanej $\mathrm{w}$ zależności od stanu cywilnego, miejsca zamieszkania i wykształcenia respondentów. Ponadto, takie cechy zwiazane ze zdrowiem, jak występowanie chorób, stosowanie leków, problemy $\mathrm{z}$ gryzieniem, żuciem, połykaniem czy posiadanie protezy zębowej również nie różnicowały istotnie gru- py pod względem częstości spożycia warzyw ogółem (Tabela 1). Jedyną istotną różnicę w tym obszarze zaobserwowano dla osób, u których nastapiło obniżenie lub utrata apetytu. U takich osób częstość spożywania warzyw ogółem była istotnie mniejsza niż u osób $\mathrm{z}$ dobrym apetytem. W przypadku częstości spożywania owoców ogółem również nie wykazano istotnych różnic w zależności od występowania chorób, stosowania leków, problemów z połykaniem czy utrata apetytu. Natomiast osoby stosujace protezy zębowe, $\mathrm{u}$ których występowały problemy $\mathrm{z}$ gryzieniem i żuciem, deklarowały istotnie statycznie mniejszą częstość spożywania owoców niż osoby, które nie zgłaszały takich problemów. Zaobserwowana zależność jest zgodna z wynikami innych badań wskazujących, że $11 \%$ osób korzystających $z$ protez zębowych zgłasza problemy podczas spożywania surowych owoców (NAWROCKA-FURMANEK i MIERZWIŃSKA-NASTALSKA 2009).

Przeanalizowano również częstość spożywania warzyw i owoców w zależności od wybranych zachowań żywieniowych, takich jak stosowanie suplementów diety, liczba posiłków w ciagu dnia czy spożywanie warzyw i owoców $z$ poszczególnymi posiłkami, lecz żadna $z$ analizowanych cech nie różnicowała istotnie statycznie grupy. Warzywa i owoce były spożywane przez respondentów głównie podczas obiadu (64\% osób) oraz między posiłkami (62\%), natomiast spożycie tych produktów najrzadziej występowało podczas kolacji (31\% osób) (Ryc. 1). W badaniu prze- 


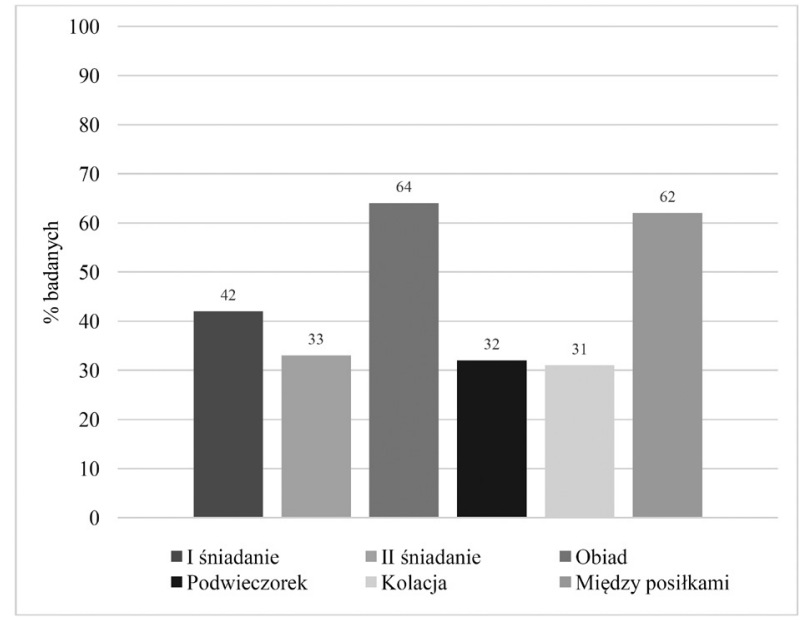

Rycina 1. Odsetki badanych deklarujacych spożywanie warzyw i owoców $z$ poszczególnymi posiłkami

prowadzonym wśród słuchaczy UTW $z$ Warszawy, respondenci również preferowali spożywanie warzyw i owoców w czasie dwóch posiłków, lecz były to obiad i II śniadanie (TOKARZ i współaut. 2007).

\section{WARZYWA SPOŻYWANE PRZEZ OSOBY STARSZE}

Na Ryc. 2 i 3 przedstawiono odsetki kobiet i mężczyzn deklarujących spożywanie poszczególnych grup warzyw i owoców w ciagu ostatnich 3 miesięcy (grudzień, styczeń, luty). Do warzyw, potraw warzywnych i ich przetworów spożywanych przez najwięcej kobiet należały: zupy jarzynowe, warzywa krzyżowe, marchew, sałatki i surówki $z$ warzyw mieszanych, cebulowe i pomidory (9790\% badanych kobiet), natomiast statystycznie mniej respondentek, $\mathrm{w}$ porównaniu do zup, spożywało paprykę, strączkowe, sałatę, suche straczkowe, warzywa liściaste i ogórki (89-78\%). Odsetki mężczyzn spożywajacych większość grup warzyw mieściły się w zakresie 100\% (marchew, cebulowe) do 79\% (ogórki). Statystycznie istotnie mniej respondentów włączało do swojej diety strączkowe świeże $(74 \%)$ i straczkowe suche $(58 \%)$ niż marchew i cebulę. Istotna statystycznie różnicę między kobietami (79\%) i mężczyznami (53\%) wykazano dla deklarowanego spożywania zielonych warzyw liściastych. Stosunkowo małe urozmaicenie asortymentu wybieranych warzyw mogło wynikać zarówno $z$ preferencji i przyzwyczajeń respondentów, jak również $z$ faktu, że badanie było przeprowadzone w marcu, gdy miejscem zaopatrzenia w te produkty sa głównie sklepy, natomiast brak jest warzyw i owoców uprawianych we własnym zakresie.

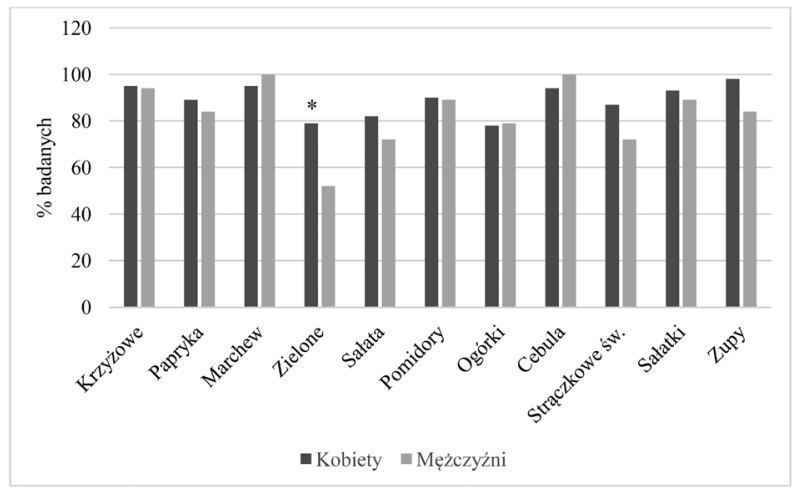

Rycina 2. Odsetki kobiet i mężczyzn deklarujących spożywanie poszczególnych grup warzyw i ich przetworów (* różnice istotne statystycznie między kobietami i mężczyznami, test $\mathrm{Chi}^{2}$ )

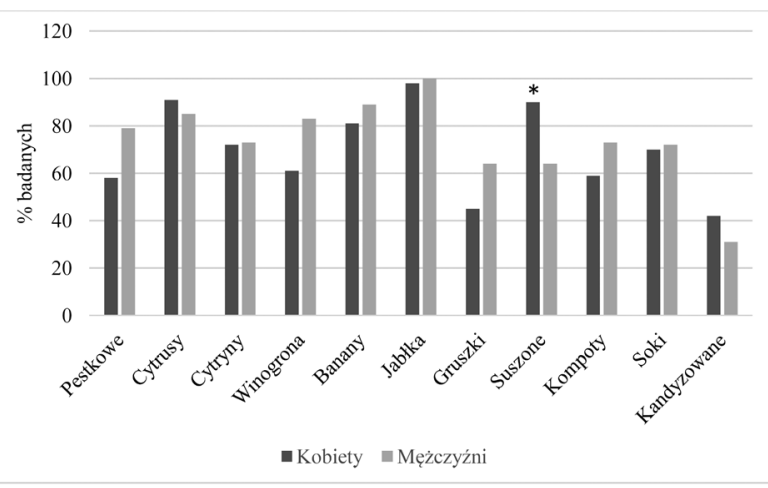

Rycina 3. Odsetki kobiet i mężczyzn deklarujących spożywanie poszczególnych grup owoców i ich przetworów (* różnice istotne statystycznie między kobietami i mężczyznami, test $\mathrm{Chi}^{2}$ )

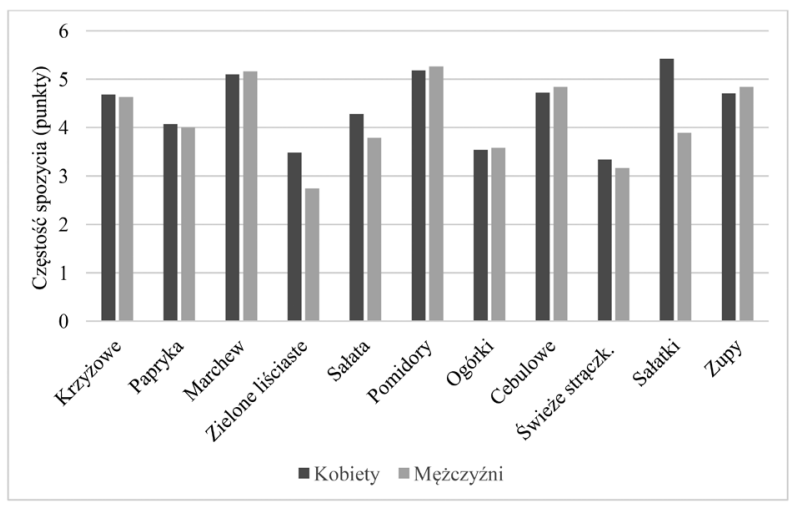

Rycina 4. Średnie częstości spożycia poszczególnych grup warzyw i ich przetworów przez kobiety i mężczyzn (1pkt - nigdy, 2 pkt $1 \mathrm{x} /$ mies., 3 pkt $-2-3 \mathrm{x} /$ mies., $4-1-2 \mathrm{x} /$ tydz., 5 - 3-4x/tydz., 6 - 5-6x/tydz., 7 - 1x lub więcej/ dzień) 
Również nie wykazano różnic w częstości spożywania poszczególnych grup warzyw (Ryc. 4) między kobietami i mężczyznami. Do najczęściej spożywanych warzyw (około 3-4 razy $w$ tygodniu) należały sałatki i surówki $z$ warzyw mieszanych, pomidory i marchew. Żadna $z$ grup warzyw nie była spożywana przez respondentów codziennie. Także wśród zdrowych osób dorosłych (średnia wieku kobiet 55 lat, mężczyzn 64 lata) z Dolnego Ślaska w badaniu prowadzonym w ciagu całego roku najczęściej spożywanymi warzywami były pomidory i marchew (ZABŁOCKA-SŁOWIŃSKA i współaut. 2012).

\section{OWOCE SPOŻYWANE PRZEZ OSOBY STARSZE}

W przypadku owoców zaobserwowano mniejsze urozmaicenie wybieranych produktów. Najwięcej kobiet spożywało w ciagu 3 miesięcy poprzedzających badanie: jabłka, cytrusy (bez cytryn), suszone owoce i banany $(97-90 \%$ badanych kobiet). Statystycznie mniej respondentek spożywało pozostałe owoce, przy czym podobne odsetki kobiet włączały do swojej diety: banany, cytryny oraz soki, nektary i napoje owocowe (82$70 \%)$, a mniejsze odsetki (61-52\%): winogrona, owoce pestkowe i gruszki. Nie wykazano różnic w liczbie mężczyzn deklarujących spożywanie najbardziej popularnych owoców, tj. jabłek, bananów, cytrusów, winogron i owoców pestkowych (100-79\%). Statystycznie mniej mężczyzn niż po jabłka, sięgało po inne owoce $i$ ich przetwory, tj. cytryny, kompoty, soki, nektary i napoje, gruszki oraz suszone owoce (74-32\%). Wykazano istotna statycznie różnicę między kobietami i mężczyznami jedynie dla owoców suszonych; więcej kobiet $(90 \%)$ niż mężczyzn (63\%) spożywało owoce $\mathrm{w}$ takiej formie. W badaniach prowadzonych wcześniej $\mathrm{w}$ pięciu regionach Polski (brak informacji o jakiej porze roku zbierano dane) wykazano, że najpopularniejszymi owocami wśród osób starszych były jabłka i gruszki łącznie i spożywało je 83\% osób starszych, owoce pestkowe, które spożywało $70 \%$ respondentów i banany spożywane przez 38\% badanych (NIEDźWIECKA i WAQDOŁOWSKA 2010).

Stwierdzono także, że kobiety częściej spożywały owoce cytrusowe, jabłka, owoce suszone i kandyzowane, a mężczyźni istotnie częściej niż kobiety spożywali kompoty (Ryc. 5). Częstsze spożywanie warzyw i owoców przez kobiety niż przez mężczyzn, pomimo większego spożycia produktów ogółem przez mężczyzn, jest wykazywane także w zagranicznych badaniach, a dorosłe mieszkanki Kanady charakteryzowały się nawet 2,5 razy większym spożywaniem większej

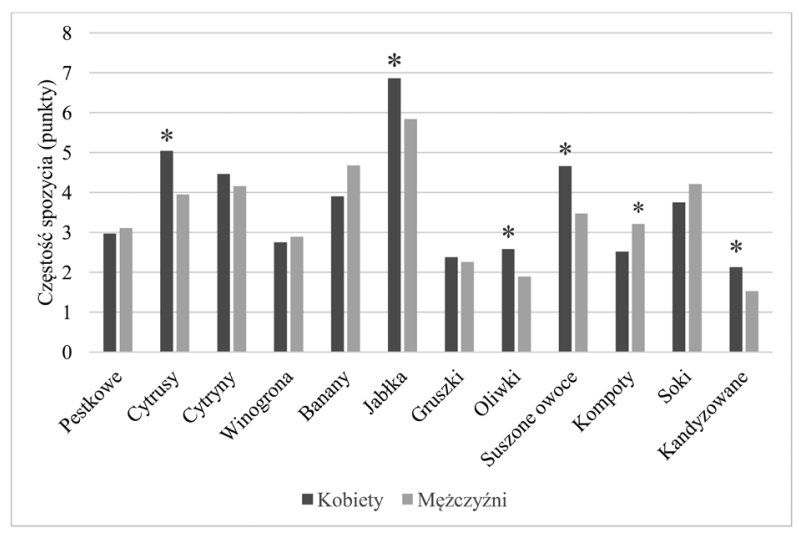

Rycina 5. Średnie częstości spożycia poszczególnych grup owoców i ich przetworów przez kobiety i mężczyzn (1pkt - nigdy, 2 pkt $-1 \mathrm{x} /$ mies., 3 pkt $-2-3 x /$ mies., $4-1-2 x /$ tydz., $5-3-4 x /$ tydz., $6-5-6 x /$ tydz., 7 - 1x lub więcej/dzień)

ilości warzyw i owoców niż mężczyźni (DEHGHAN i współaut. 2011).

\section{WIEDZA ŻYWIENIOWA A CZESTOŚĆ SPOŻYWANIA WARZYW I OWOCÓW PRZEZ OSOBY STARSZE}

Fakt rzadkiego spożywania warzyw i owoców w ciagu dnia oraz nieuwzględnienia ich we wszystkich posiłkach może wiazać sie z niska wiedza żywieniowych respondentów. Analizując odpowiedzi na pytania dotyczące wiedzy respondentów stwierdzono, że jedynie $32 \%$ badanych wskazało prawidłowo zalecana do spożycia w ciagu dnia liczbę porcji warzyw i owoców. Także 32\% respondentów prawidłowo wskazało 5 lub 6 składników prozdrowotnych występujących $\mathrm{w}$ produktach $\mathrm{z}$ tych grup. Podobne wyniki dotyczące wiedzy żywieniowej uzyskano w badaniu WOBASZ, w którym stwierdzono niski poziom wiedzy żywieniowej respondentów, szczególnie w kwestii prozdrowotnych efektów spożywania warzyw i owoców na zalecanym poziomie (WAŚKIEWICZ i współaut. 2008). Chociaż największa częstością spożycia warzyw $(7,83 \pm 0,37$ pkt) charakteryzowali się respondenci, którzy uważali, że trzeba jeść 5 lub więcej porcji tych produktów $\mathrm{w}$ ciagu dnia, to nie stwierdzono różnicy $\mathrm{w}$ tym zakresie $\mathrm{z}$ osobami, które uważały, że wystarczy jeść 1-2 porcje na dzień $(6,15 \pm 1,17$ pkt). Takiej zależności nie wykazano dla owoców. Także osoby udzielajace 5-6 poprawnych odpowiedzi na pytanie dotyczące składników występujących w owocach i warzywach miały największą częstość spożywania warzyw i owoców wyrażoną $\mathrm{w}$ punktach, ale nie różniąca się statystycznie od osób mających mniejszą wiedzę w tym zakresie. 
Tabela 2. Częstość spożycia warzyw i owoców w zależności od wiedzy żywieniowej (bez osób z częstotliwością spożycia $<3-4 \mathrm{x} /$ tydz.).

\begin{tabular}{|c|c|c|c|c|c|c|c|c|c|c|c|}
\hline \multirow{5}{*}{$\begin{array}{l}\text { Odpowiedź na } \\
\text { pytanie }\end{array}$} & \multirow{5}{*}{$\begin{array}{l}\text { Liczba } \\
\text { osób w } \\
\text { kategorii }\end{array}$} & \multicolumn{5}{|c|}{ Warzywa } & \multicolumn{5}{|c|}{ Owoce } \\
\hline & & \multicolumn{4}{|c|}{$\begin{array}{l}\text { Liczba osób deklarujących } \\
\text { określoną częstość spoży- } \\
\text { wania }\end{array}$} & \multirow{4}{*}{$\begin{array}{l}\text { Test Chi }{ }^{2} \\
\text { (wartość } p \text { ) }\end{array}$} & \multicolumn{4}{|c|}{$\begin{array}{l}\text { Liczba osób deklarujących } \\
\text { określoną częstość spoży- } \\
\text { wania }\end{array}$} & \multirow{4}{*}{$\begin{array}{l}\text { Test } \mathrm{Chi}^{2} \\
\text { (wartość } p \text { ) }\end{array}$} \\
\hline & & \multicolumn{2}{|c|}{ w tygodniu } & \multicolumn{2}{|c|}{ na dzień } & & \multicolumn{2}{|c|}{ w tygodniu } & \multicolumn{2}{|c|}{ na dzień } & \\
\hline & & $3-4$ & $5-6$ & 1 & $2-3$ & & $3-4$ & $5-6$ & 1 & $2-3$ & \\
\hline & & razy & razy & $\mathrm{raz}$ & razy & & razy & razy & $\mathrm{raz}$ & razy & \\
\hline \multicolumn{12}{|c|}{ Zalecana liczba porcji warzyw i owoców w ciagu dnia } \\
\hline 1 lub 2 & 13 & 2 & 1 & 8 & $\mathrm{O}^{\#}$ & 0,0134 & 0 & 2 & 4 & 7 & NS \\
\hline 3 & 33 & 6 & 5 & 13 & 6 & & 4 & 4 & 12 & 13 & \\
\hline 4 & 15 & 3 & 7 & 2 & 3 & & 1 & 5 & 2 & 6 & \\
\hline 5 i więcej & 29 & 3 & 3 & 7 & 16 & & 1 & 4 & 7 & 16 & \\
\hline
\end{tabular}

Składniki pokarmowe występujące w warzywach i owocach - liczba poprawnych odpowiedzi

\begin{tabular}{llllllllllll}
\hline$\leq 2$ & 15 & 1 & 4 & 8 & 2 & NS & 4 & 3 & 5 & $3^{\wedge}$ & 0,0365 \\
$3-4$ & 45 & 9 & 10 & 12 & 11 & & 2 & 9 & 15 & 19 \\
$5-6$ & 29 & 4 & 2 & 10 & 12 & & 0 & 3 & 5 & 20 &
\end{tabular}

NS - $p>0,05$; \#istotna różnica $\mathrm{w}$ stosunku do osób sądzących, że należy spożywać 4 porcje $(p=0,0120)$ oraz $\geq 5$ porcji $(p=0,0181)$; ^istotna różnica w stosunku do osób z 5-6 poprawnymi odpowiedziami $(p=0,0248)$.

Natomiast $w$ podgrupie poprawnie odpowiadajacych na pytanie o zalecana liczbe porcji warzyw i owoców było proporcjonalnie więcej osób (55\%) spożywających warzywa 2-3 razy dziennie niż wśród respondentów uważających, że wystarczy jeść mniej niż 5 porcji dziennie (15\%). Takiej zależności nie wykazano dla częstości spożycia owoców ogółem. Ponadto wśród osób, które bardziej prawidłowo odpowiedziały na pytanie dotyczące składników prozdrowotnych występujacych w warzywach i owocach było więcej respondentów charakteryzujacych się spożyciem owoców 2-3 razy dziennie (69\%) niż wśród tych, którzy mieli mniejsza wiedzę w tym zakresie (37\%) (Tabela 2).

Wskazuje to na potrzebę edukacji osób starszych, co potwierdzaja badania BREWER i współaut. (2016) przeprowadzone w USA, w których zaobserwowano istotny wzrost spożycia warzyw i owoców oraz ich różnorodności w grupie osób starszych uczestniczacych w programie edukacji żywieniowej, w porównaniu do grupy nieedukowanej.

\section{PODSUMOWANIE}

Mimo iż warzywa i owoce odgrywaja istotną rolę $\mathrm{w}$ żywieniu osób starszych, to większość seniorów nie spożywa tych produktów $z$ zalecaną częstotliwością (5 porcji dziennie) ani $\mathrm{w}$ zalecanych ilościach (powinny stanowić co najmniej połowę tego co się spożywa w ciagu dnia). Ponieważ zalecenia realizowane sa $\mathrm{w}$ większym stopniu przez osoby $\mathrm{z}$ większą wiedza żywieniowa, istotnym wydaje się kontynuowanie programów edukacyjnych dla tej grupy populacyjnej. Szczególna uwagę należałoby zwrócić na pokonywanie trudności, które moga się pojawiać przy pozyskiwaniu, przygotowywaniu, a także konsumpcji warzyw i owoców przez osoby starsze obciażone problemami związanymi ze stanem zdrowia, sytuacją rodzinna czy finansowa.

$$
\text { Streszczenie }
$$

Jednym $z$ kluczowych elementów dla zdrowego starzenia się jest prawidłowe żywienie, $w$ tym odpowiednia ilość i rodzaj spożywanych warzyw i owoców, jednakże seniorzy zazwyczaj nie jedzą wystarczającej ilości produktów $\mathrm{z}$ tych grup. W artykule przedstawiono dane na temat roli owoców i warzyw w zmniejszaniu ryzyka wystapienia takich chorób, jak schorzenia układu krażenia, osteoporoza, przewlekła obturacyjna choroba płuc, depresja, zaburzenia funkcji poznawczych, niektóre rodzaje nowotworów, a także umieralności. W tym kontekście zaprezentowano wyniki własnych badan ankietowych dotyczacych częstości spożywania 11 grup warzyw i owoców przez osoby starsze $(91$ respondentów, w tym 71 kobiet i 19 mężczyzn). Wskazuja one na niezadawalającą realizację zaleceń żywieniowych. Częstsze spożywanie tych produktów zaobserwowano wśród kobiet, u osób $z$ wyższym wykształceniem, u stosujących leki lub specjalną dietę. Posiadanie protezy zębowej istotnie zmniejszało spożycie owoców. Większa wiedza żywieniowa dotycząca owoców i warzyw związana była $z$ częstszym spożyciem tych produktów. W związku $z$ powyższym, prowadze- 
nie żywieniowych programów edukacyjnych wydaje się szczególnie istotne wśród osób starszych.

\section{LITERATURA}

Bellavia A., LaRsson S. C., BotTai M., WolK A., ORSINI N., 2013. Fruit and vegetable consump tion and all-cause mortality: a dose-response analysis. Am. J. Clin. Nutr. 98, 454-459.

Biagi E., Candela M., TurRoni S., Garagnani P., FRANCESCHI C., BRIGIDI P., 2013. Ageing and gut microbes: perspectives for health maintenance and longevity. Pharmacol. Res. 69, 1120.

BoffetTA P., Couto E., WichmanN J. i współaut. 2010. Fruit and vegetable intake and overall cancer risk in the European Prospective Investigation into Cancer and Nutrition (EPIC). J. Natl. Cancer Inst. 102, 529-537.

BREwer D., Dickens E., Humphrey A., STEPHENSON T., 2016. Increased fruit and vegetable intake among older adults participating in Kentucky's Congregate Meal Site Program. Educ. Gerontol. 42, 771-784.

Claesson M. J., Jeffery I. B., Conde S., PowER S. E., O'CONNOR E. M., CUSACK S. i współaut., 2012. Gut microbiota composition correlates with diet and health in the elderly. Nature 488, 178-184.

ClifFord J., Niebaum K., Bellows L., 2010. Di etary Fibre Fact. Sheet No. 9.333. Colorado State University Extension. Food and Nutrition Series. Health.

Dehghan M., AKhtar-Danesh N., Merchant A. T., 2011. Factors associated with fruit and vegetable consumption among adults. J. Hum. Nutr. Diet. 24, 128-134.

DuthiE S. J., Duthie G. G., Russell W. R., Kyle J. A. M., MACRIARMID J. L., RUNGAPAMESTRY V., Stephen S., MEgias-BaeZa C., Kaniewska J. J., SHAW L., MILNE L., BREMNER D., RosS K., Morrice P., Pirie L. P., Horgan G., BestWICK C. S., 2018. Effect of increasing fruit and vegetable intake by dietary intervention on nutritional biomarkers and attitudes to di etary change: a randomised trial. Eur. J. Nutr. 57, 1855-1872.

Fulton S. L., Mc Kinley M. C., Neville C. E., BALDRICK F. R., Mulligan C., MCCALl D., MCCANCE D. R., EDGAR J. D., ElBORN J. S., YOUNG I. A., PATTERSON C. C., WOODSIDE J. V., 2017. The effect of increased fruit and vegetable consumption on selected macronutrient and micronutrient intakes in four randomisedcontrolled trials. $\mathrm{Br}$. J. Nutr. 117, 1270-1278.

HE F. J., NOWson C. A., LuCAS M., MACGREGOR G. A., 2007. Increased consumption of fruit and vegetables is related to a reduced risk of coronary heart disease: meta-analysis of cohort studies. J. Hum. Hypertens. 21, 717 728.

JAROSZ M., 2018. Piramida zdrowego żywienia $i$ aktywności fizycznej dla osób $w$ wieku starszym. Instytut Żywności i Żywienia, Warszawa.

Jiang X., Huang J., Song D., Deng R., Wei J., ZHANG Z., 2017. Increased consumption of fruit and vegetables is related to a reduced risk of cognitive impairment and dementia: meta-analysis. Front. Aging Neurosci. 9, 1828.

KatuŻa J., LaRsson S. C., ORsini N., Linden A., WolK A., 2017. Fruit and vegetable consumption and risk of COPD: a prospective cohort study of men. Thorax 72, 500-509.
KASHINO I., MizOUE T., TANAKA K. i współaut., 2015. Vegetable consumption and colorectal cancer risk: an evaluation based on a systematic review and meta-analysis among the Japanese population. Japn. J. Clin. Oncol. 45, 973-979.

KLICH-RACZKA A., SiUdA J., PIOTROWICZ K., BOCZARSKA-JEDYNAK M., SKALSKA A., PRZYSTANEK E., WiZner B., ŚWiAT M., SKrZYPEK M., OPALA G., GRODZICKI T., 2012. Zaburzenia funkcji poznawczych u osób $w$ starszym wieku. [W:] Aspekty medyczne, psychologiczne, socjologiczne $i$ ekonomiczne starzenia się ludzi $w$ Polsce. Mossakowska M., WIĘCEK A., BŁęDOWSKI P. (red.). Termedia, Poznań, 109-121.

Kumar M., BABAei P., Ji B., Nielsen J., 2016. Human gut microbiota and healthy aging: recent developments and future prospective. Nutrit. Healthy Aging 4, 3-16.

LATTIMER J. M., HAUB M. D., 2010. Effects of dietary fibre and its components on metabolic health. Nutrients 2, 1266-1289.

Li B., LI F., WANG L., ZHANG D., 2016. Fruit and vegetables consumption and risk of hypertension: a meta-analysis. J. Clin. Hypertens. 18, 468-476.

LIU X., YAN Y., Li F., ZHANG D., 2016. Fruit and vegetable consumption and risk of depression: a meta-analysis. Nutrition, 32, 296-302.

MuJCIC R., Oswald A. J., 2016. Evolution of wellbeing and happiness after increases in consumption of fruit and vegetables. Am. J. Publ. Health 106, 1504-1510.

NAWROCKA-FURMANEK J., MIERZWIŃSKA-NASTALSKA E., 2009. Badania ankietowe funkcji żucia $w$ grupie pacjentów $z$ czéściowymi brakami uzębienia $w$ zależności od jego stanu. Protet. Stomatol. 4, 266-272.

NguYen B., BAUMAN A., Gale J., Banks E., KRITHARIDES L., DING D. 2016. Fruit and vegetable consumption and all-cause mortality: evidence from a large Australian cohort study. Int. J. Behav. Nutr. Phys. Act. 13, 9-18.

NGuYen B., Ding D., MinRshaHI S., 2017. Fruit and vegetable consumption and psychological distress: cross-sectional and longitudinal analyses based on large Australian sample. BMJ Open 7, e014201.

NickleTt E. J., KADELl A. R., 2013. Fruit and vegetable intake among older adults: a scoping review. Maturitas 75, 305-312.

NiEDŹWIECKA E., WĄDOŁOWSKA L., 2010. Analiza urozmaicenia spożycia żywności $w$ kontekście statusu socjoekonomicznego polskich osób starszych. Probl. Hig. Epidemiol. 91, 576-584.

Oyebode O., Gordon-Dseagu V., Walker A., MinDELL J., 2014. Fruit and vegetable consumption and all-cause, cancer and CVD mortality: analysis of Health Survey for England data. J. Epidemiol. Community Health 68, 856862.

PARK H. M., HeO J., PARK Y., 2011. Calcium from plant sources is beneficial to lowering the risk of osteoporosis in postmenopausal Korean women. Nutr. Res. 31, 27-32.

Pastor-Valero M., Furlan-Viebig R., Menezes P. R., Da Silwa S. A., Vallada H., ScazUfCa M. 2014. Education and WHO recommendations for fruit and vegetable intake are associated with better cognitive function in a disadvantaged Brazillian elderly population: a population-based cross-sectional study. PLoS One 9, e94042.

PUŻYŃSKI S., 2009. Depresje i zaburzenia afektywne. PZWL, Warszawa. 
Rautiainen S., Levitan E. B., MitTleman M. A., WolK A., 2015. Fruit and vegetable intake and rate of heart failure: a population-based prospective cohort of women. Eur. J. Heart Fail. 17, 20-26.

RÉMOND D., SHAHAR D. R., GILlE D., PINTO P., Kachal J., PEYRon M-A., Dos SANTOS C. N., WALTher B., BORDONI A., DUPONT D., TOMÁSCoBos L., VERGÈRES G., 2015. Understanding the gastrointestinal tract of the elderly to develop dietary solutions that prevent malnutrition. Oncotarget 6, 13858-13898.

Santoro A., Pini E., Scurti M., Palmas G., BeRENDSEN A., BRZOZOWSKA A., PIETRUSZKA B., SZCZECINSKA A., CANO N., MEUNIER N., DE Groot C.P., FESKens E., FAIRWEATHER-Tait S., SALVIOLI S., CAPRI M., BRIGIDI P., FRANCESCHI C., 2014. Combating inflammaging through a Mediterranean whole diet approach: the NU$A G E$ project's conceptual framework and design. Mech. Ageing Dev. 136-137, 3-13.

SHWINGSHACKL L., HOFFMANN G., LAMPOUSI A.-M., KNÜPPEL S., IQBAL K., SChWEDHELM C., BeCHTHOLD A., SCHLESINGER S., BOEING H., 2017. Food groups and risk of type 2 diabetes mellitus: a systematic review and meta-analysis of prospective studies. Eur. J. Epidemiol. 32, 363-375.

TOKARZ A., Stawarska A., KolczewsKa M., 2007. Ocena jakościowa sposobu żywienia ludzi starszych zrzeszonych $w$ wybranych war- szawskich stowarzyszeniach społecznych. Bromat. Chemia Toksykol. 4, 359-364.

WAŚKIEWICZ A., PIOTROWSKI W., SYGNOWSKA E., BRODA G., DRYGAS W., ZDROJEWSKI T., KOZAKIEWICZ K., TYKARSKI A., BIELA U., 2008. Quality of nutrition and health knowledge in subjects with diagnosed cardiovascular diseases in the Polish population - National Multicentre Health Survey (WOBASZ). Kardiol. Pol. 5, 507-513.

WHO, 2015a. World report on ageing and health. World Health Organization, Geneva.

WHO, 2015b. Number of people over 60 years set to double by 2050; major societal changes required. Saudi Med. J. 36, 1375-1376.

ZABŁOCKA-SŁOWIŃSKA K., PRESCHA A., PIECZYŃSKA J., WYKA J., GOŁECKI M., KOSACKA M., POREBSKA I., GRAJETA H., JANKOWSKa R., BIERNAT J., 2012. Ocena częstotliwości spożycia warzyw $i$ owoców przez chorych na raka płuca i osoby zdrowe. Probl. Hig. Epidemiol. 93, 838-848.

Zielińska M. A., BiAeECKA A., PietruszKa B., HAMUŁKA J., 2017. Warzywa i owoce jako źródła wybranych substancji bioaktywnych $i$ ich wpływ na funkcje poznawcze u osób starszych. Postep. Hig. Med. Dosw. 71, 267-280.

KOSMOS Vol. 68, 2, 293-301, 2019

Maria Szmidt, Dominika Granda, Adrian Broda, Anna Brzozowska

Department of Human Nutrition, Faculty of Human Nutrition and Consumer Sciences, Warsaw University of Life Sciences, 159C Nowoursynowska Str.,02-776 Warszawa,E-mail: maria_szmidt@sggw.pl

THE ROLE OF VEGETABLES AND FRUITS IN THE DIET OF THE ELDERLY

\section{Summary}

One of the key elements for healthy aging is proper nutrition, including the amount and type of fruit and vegetables consumed. However, the seniors usually don't eat enough products from these groups. This paper provides an overview on the role of fruits and vegetables in decreasing risk of such diseases as CVD, osteoporosis, COPD, depression, impairment of cognitive functions, some type of cancers as well as mortality. In this context, results of our own questionnaire studies on the frequency of vegetables and fruits consumption (11 groups) by older people (91 respondents, including 71 women and 19 men) are presented. They indicate that the fulfilment of the nutritional guidelines was unsatisfactory. More frequent consumption has been observed among women, participants with higher education and those using medications/special diet. Having a denture significantly reduced the consumption of fruits. Higher nutritional knowledge about vegetables and fruits was associated with a more frequent consumption. Therefore, broadening of nutritional education seems to be particularly important among the older people. 